\title{
Seeing like a city: how tech became urban
}

\author{
Sharon Zukin ${ }^{1}$ \\ Published online: 15 August 2020 \\ (C) Springer Nature B.V. 2020
}

\begin{abstract}
The emergence of urban tech economies calls attention to the multidimensional spatiality of ecosystems made up of people and organizations that produce new digital technology. Since the economic crisis of 2008, city governments have aggressively pursued economic growth by nurturing these ecosystems. Elected officials create public-private-nonprofit partnerships to build an "innovation complex" of discursive, organizational, and geographical spaces; they aim not only to jump-start economic growth but to remake the city for a new modernity. But it is difficult to insert tech production space into the complicated urban matrix. Embedded industries and social communities want protection from expanding tech companies and the real estate developers who build for them. City council members, state legislators, and community organizations oppose the city government's attempts to satisfy Big Tech companies. While the city's density magnifies conflicts of interest over land-use and labor issues, the covid-19 pandemic raises serious questions about the city's ability to both oppose Big Tech and keep creating tech jobs.
\end{abstract}

Keywords Tech economy · Tech ecosystem · New York City-Economic development, Innovation district, Urban economy

Until the 2010s, digital technology seemed to have little to do with cities. A single suburban landscape, that of Silicon Valley, dominated the social imaginary of the tech world. Anyone who read the media or paid attention to popular culture knew about the area's research labs, home garages, and office parks where hard-working electrical engineers made amazing innovations in electronics. From Hewlett Packard and Intel to Apple and Google, the Valley both nurtured and symbolized the steady growth of the American computer industry in the late twentieth century. The enduring hegemony of the place is underlined by the popularity of the eponymous television series Silicon Valley, which aired from 2014 to 2019, a "comedy series," as a Google search

Sharon Zukin

szukin@gc.cuny.edu

1 CUNY Graduate Center, 365 Fifth Avenue, New York, NY 10016, USA 
describes it, that "follows the misadventures of introverted computer programmer Richard and his brainy friends as they attempt to strike it rich in a high-tech gold rush."1

Cities flared briefly in the tech narrative during the 1990s, when a new kind of tech company appeared that produced content for the fledgling World Wide Web. These "dot-com" startups and the "new media producers" who worked for them congregated in cities, notably New York and San Francisco, where they connected to strong advertising, publishing, and marketing industries. Yet the urban clusters that they formed bore nicknames that deferred to the hegemonic original: New York's Silicon Alley and Multimedia Gulch in San Francisco (Indergaard 2004; Wolfe 1999). Dotcom offices' playful aesthetics and recreational amenities got media buzz; the industry's quick success and "cool" reputation drew financial investors hoping to profit if the startup was acquired by a larger company or got a high valuation in a lucrative IPO (initial public offering of stock). By 2001, however, a drastic decline in dot-com stock values strongly suggested that a city's tech industry would never be robust enough to power the urban economy. Cities, it seemed, were not designed to produce the same quality or quantity of innovation as Silicon Valley.

Yet, during the 2010s, metropolitan cities around the world emerged as dynamic centers of a rapidly growing tech economy. This was not just because people who live and work in these cities are big users of digital technology, sending more texts on smart phones, ordering more rides on digital platforms, or streaming more hours of TV shows. Neither was it only a manifestation of the persistent digital divide that provides cities with better and faster broadband access to the internet than rural areas. In a new social imaginary, cities became core places where digital technology is produced. They are the social and cultural locus of technological innovation that makes businesses and countries winners in the global economy and enables cities themselves to become modern. Since 2010, the need to transform cities into "tech hubs" has become a high priority for government officials and business leaders in places as different as Beijing, Milan, Helsinki, and New York.

This locational relationship is not completely new. In the late nineteenth and early twentieth centuries, technology was embedded in cities to shape the foundational concepts, images, and governing regimes of the cultural outlook identified with modernity. In cities, the historian Miriam R. Levin (2010) writes, new ideas of progress were discussed, refined, and tested by groups of leading scientists, bankers, industrialists, and government officials who would "design and steer the process of modernization." Business and political elites applied scientific ideas to technical tasks both to change the landscape of the city and to develop more efficient means of social control. Great, glass-domed railroad stations, electric streetlamps, subway systems, and sewers created an infrastructure of modern metropolitan life more recognizable, and more architecturally distinguished, than today's public WiFi hotspots, bike share stations, and coworking spaces.

Three things changed around 2010 to bring big cities, especially national capitals of finance and media, to the forefront of the tech economy. First, digital technology

\footnotetext{
${ }^{1}$ Although I am writing only about US experience, Silicon Valley enjoys a global hegemony in the social imaginary of digital technology, with Silicon Glen popping up in Scotland, Silicon Roundabout in East London, and Silicon Wadi on Israel's Mediterranean coast. Even in south China, the name of the Greater Bay Area, stretching from Guangzhou to Hong Kong and Macau and formerly known as the Pearl River Delta, evokes a connection with the older tech region located between San Francisco, Palo Alto, and San Jose.
} 
changed. The development and rapid diffusion of smart phones in the early 2000 s led to a profusion of "apps," applications of digital technology that were accessed electronically and directed to both businesses and consumers. Apps benefited from big cities as both platforms for conceptualizing and launching new products and markets connecting capital, labor, and design. Although the software was universal, its adoption enhanced the social and cultural capital of local places in dense urban environments. As design centers, these cities attracted app developers. Ordinary city dwellers also showed themselves remarkably willing to perform unpaid work to create content for digital "communities" and connect to them anytime and anywhere (Terranova 2000). Remarkably, a "Yelp effect," intensified by Instagram "influencers," turned users' reviews of local businesses and photos of neighborhoods into status differentials and brought more visitors, tourists, and customers to local "hotspots" (see, for example, Boy and Uitermark 2017).

Moreover, platforms that were introduced in the early 2000s responded to needs and wants that were particularly acute in urban areas. Uber, for example, offered new means of physical mobility to get around cities while Google Maps and Airbnb made it easier to navigate them "like a local." High demand for services and housing encouraged financially strapped residents to use digital platforms like TaskRabbit to get a job, or a second job, and turn apartments into short-term rentals on Airbnb (Ravenelle 2019; Semi and Tonetta 2020). For their part, big electronics corporations like IBM, Cisco, and Siemens understood that outdated, underfunded infrastructure serving a growing urban population under the stress of climate change presented a vast market for all kinds of "smart cities" equipment, and they could persuade city governments that had underfunded infrastructure for years to subsidize its development and buy it (Clark 2020). All this created more demand for content in and about cities and more digital platforms to access it.

The second thing that changed was human capital: app developers came to live in cities. After the financial crisis of 2008 forced banks and other businesses to cut employment, traditional career paths disappeared. Many college graduates no longer aspired to be investment bankers; now they wanted to be software engineers and app developers. The mobility of new tools of production, from smart phones to software development kits, and the ease of accessing "the cloud" for both programming components and data storage, enabled them to live anywhere - in San Francisco, say, instead of in Silicon Valley. And many of them preferred to live in cities where they could easily find tech work, as well as collaborate and socialize with other young adults like themselves. By 2012, the urban economic researcher Richard Florida (2012) wrote, both startups and established tech companies were opening in, or moving to, cities, to be "where young techies prefer to live, work and play."

Most important, however, in addition to technological change and shifts in careers, city governments devised a new activist approach to business development. Since the 1970s, they had taken an "entrepreneurial" view of public services: outsourcing the work of city agencies to the private sector, reducing social welfare benefits, and promoting cultural attractions to compete with other cities for investors and tourists (Harvey 1989; Greenberg 2008). But after the Great Recession of 2008, they turned to the tech industry for a new growth strategy. If the financial industry was unstable and the national government was stingy, "innovation" would be the key to urban jobs and fiscal solvency. Mayors who had barely learned to use email now talked about 
nurturing tech startups. In every major city, an "innovation complex" arose, with a built environment of computer research labs, tech and creative offices, and coworking spaces; an organizational environment of partnerships among tech companies, universities, and economic development agencies; and a discourse of "innovation and entrepreneurship" (Zukin 2020).

A fictional scenario (Beckert 2016) of tech-based urban economic growth was not unthinkable. The many businesses and organizations that were already operating in big cities offered a broad market for digitization. Tech startups and their customers formed new fields in the urban economy, from fintech for banks and other financial institutions to proptech for real estate and construction companies and property managers, and healthtech for hospitals and insurers. Saas, software as a service, became a "thing"; tech jobs multiplied. Even Domino's Pizza and Goldman Sachs now implemented digital systems and called themselves tech companies (Brooker 2015; Kelso 2018).

Although the sequence of growth from industry to finance to digital technology seems to be a "natural" adaptation to changing technology and markets, innovation policies were deliberately adopted by government officials in places and regions with very different state structures, legal frameworks, and cultural traditions. In large part, the shift to an urban tech economy reflects their attempt to respond to competition in global markets by rekindling the charisma of capitalism (Thrift 2001; Boltanski and Chiapello 2005). In Europe, the effort to compete for regional and foreign investment led city governments and business leaders to reimagine industrial wastelands as science and media centers of the twenty-first century; the 22@District in Barcelona was an early example. In China, where policies were not driven by fiscal austerity, national and local governments plowed investment into simultaneous urban development and advanced tech industrial capacity, achieving the most dramatic results in the southern city of Shenzhen, which morphed from a small group of rural villages into one of the country's "Silicon Valleys." In the United States, rapid growth of tech companies and tech jobs promoted a small number of "superstar" cities, beginning with San Francisco, Boston, and New York (Moretti 2012). ${ }^{2}$

By 2015, New York City had risen from the dot-com dust to become the second largest "startup ecosystem" in the world (Compass 2015). As a sociologist in New York, I was intrigued. How did digital technology become urban? Or, how did technology become urban again?

\section{Social construction of tech space}

Sociologists have paid little attention to where digital technology is produced, leaving that question to historians and economists. Neither are they interested in how businesses decide to locate in one place or another, relegating that issue to geographers. For urban sociologists, who often still take their cue from the ethnographies of the Chicago School, the norm is to study people, neighborhoods, and housing rather than business

\footnotetext{
2 "Superstar" was first used by economists to categorize cities like San Francisco and New York with large numbers of rich residents who outbid others for scarce housing (Gyourko et al. 2006), and then the term was expanded to depict cities with the largest concentrations of the highest-paying jobs, which happen to be tech jobs. This rarified category comprises not only San Francisco and New York, but also Boston, Seattle, and Washington DC in the United States, and London and Paris in Europe.
} 
or industry. Yet, for organizational and economic sociologists, the archetypal spaces where society is formed are institutional, not geographical; the workplaces they study could just as well be in Nairobi as in Chicago. Certainly, sociologists have produced great macrolevel analyses of new economic structures, from Max Weber's interpretation of the emergence of western capitalism to Immanuel Wallerstein's historical examination of the rise of the modern world system. But most economic sociologists today are not concerned with the spatial meso-level; still less are they interested in relating organizational and technological innovation to specific urban places. To some degree, this reflects economic sociologists' preoccupation with organizations and their retreat, with the postwar diffusion of Keynesianism and Fordism, from grappling with hardcore issues of political economy (Trigilia 2007). But it also reflects the long-term distancing of urban issues from the disciplinary core of sociology.

To be fair, sociologists are not to blame for cities' absence from the tech narrative. This really reflects the long march of corporate headquarters and research labs away from urban centers throughout the twentieth century. Little by little, and more rapidly after World War II, these types of workplaces ensconced themselves in suburban office parks and campuses, building a new "pastoral capitalism" (Mozingo 2011) that separated managers and scientists from workers on the factory floor. By 1916, Westinghouse's research lab had moved from the city of Pittsburgh to one of its eastern suburbs (Vitale 2017). Bell Labs, the foremost technology research center in the United States for many years, moved from Manhattan to Northern New Jersey in the 1940s (Gertner 2012). Route 128 near Boston and the Research Triangle in North Carolina were prominent post-World War II examples of the suburbanization of technology centers (O’Mara 2005). Like Silicon Valley (Walker 2018; O’Mara 2019), the Research Triangle was shaped by a real estate deal for an industrial park whose initial investors were a land-rich university and a commercial real estate developer. ${ }^{3}$

Sociologists have had a framework to analyze this kind of development since the 1970s, when Harvey Molotch (1976) introduced the concept of "the city as a growth machine." In this view, business and political elites of "place entrepreneurs" are constantly jockeying for control of land and its uses both to grow the city and advance their fortunes. Yet the application of the growth machine model reflects both a perennial sociological bias in favor of studying residential communities and the unquestioned geographical dominance of suburban office parks in the late twentieth century. For Molotch and his 1980s coauthor John Logan (Logan and Molotch 1986), Silicon Valley was an "affluent employing suburb."

Manuel Castells (1989) broadened sociological perspectives on the places where digital technology is produced when, at the end of the 1980s, he published a threevolume tome on a global "networked society." Castells was teaching at Berkeley, a good place to observe a local ecosystem of people and organizations as it emerged around the electronics industry. However, as an urban sociologist connected to research networks around the world, he emphasized "global flows" of financial capital, computer scientists, and cultural ideas, conceptual linchpins that were further developed by

\footnotetext{
${ }^{3}$ I am citing only US examples, but suburban office and technology parks are also widespread in Britain and continental Europe and are growing in China - although cities there tend to incorporate their rural periphery, eroding urban-rural distinctions. Each country produces suburban office parks and research centers by a different constellation of state planning agencies, quasi-public authorities, companies, and universities.
} 
Castells and Hall (1994) in their comparative study of "technopoles of the world" or "twenty-first-century industrial complexes" and by Anna-Lee Saxenian (1994) in her work on Silicon Valley. However, comparing Silicon Valley's untrammeled rise with Route 128's apparent fall, Saxenian also emphasized regional institutional and cultural differences. As a result of all this work, it was no longer possible to consider concentrations of tech production as "affluent employing suburbs"; they represent regional networks of various kinds of producers whose decisions both shape and reflect global flows of human, social, and financial resources.

For both organizational sociologists and economic geographers, local places like Silicon Valley are network nodes. They both reinforce the social capital of innovators and entrepreneurs and reproduce their cultural capital. They capitalize on the advantageous amassing of tacit knowledge that the geographer Michael Storper (1995) calls "untraded interdependencies." Like sociologists' "network effects," these include social learning, peer influence, and cultural norms. Sometimes, network processes magnify preexisting advantages (DiMaggio and Garip 2012), but they can also rigidify them so that a region becomes less competitive than its rivals (Storper et al. 2015). Unlike most sociologists, researchers who want to understand economic development focus on local advantages. Castells, Saxenian, and Storper wanted to know why the tech industry develops in specific places that Castells, following European usage, called "innovation milieux."

According to Castells (1989, p. 88), innovation milieux depend on "a continuous flow" of three factors both within and outside of tech-oriented organizations: "new scientific and technological information, high-risk capital, and innovative technical labor." Economists have emphasized the importance of specialized, place-based exchanges of new ideas and techniques ever since Alfred Marshall wrote about regional industrial districts in the 1890s (Belussi and Caldari 2009). Knowledge transfer and workers' movement from firm to firm have been shown to be important for innovation, especially in Silicon Valley (Saxenian 1994). But Castells's approach is distinguished by its recognition of the importance of investment capital, especially the "venture capital" that channels wealth into tech startups.

Looking at the rapid growth of venture capital in the San Francisco Bay area since the 1960s, Castells (1989, p. 87) specifies that an innovation milieu has "a collective memory of entrepreneurial success, as well as new opportunities opened up by the existence of innovative industrialism." He calls attention to dynamic interactions among the social, political, and cultural contexts of regional economies and business strategies. People who run industries make strategic decisions for economic gain and labor control; for these reasons, they gradually moved electronics production from the East Coast to the West Coast, then from California to Texas, and eventually from the United States to Mexico and China. For Castells, the tech industry is a set of relationships that are socially and culturally embedded in a locality, but, above all, it is a business that wants cheap labor, few government restrictions, and access to investment capital.

Cities, then, became centers of modern technology in the 1990s as they did in the 1890s: because of the physical, social, and financial density that facilitates the emergence of new ideas and the coordination of capital. This does not mean that cities displaced Silicon Valley as the world's preeminent place for developing digital technology and raising capital to do it. Today, however, metropolitan networks of 
economic, political, and cultural entrepreneurs prominently promote urban innovation to prototype, manufacture, and commercialize new tech products. For this reason, it is important to understand the spatiality of tech production. Specific spaces where new cultural norms of innovation are enacted and "emplaced," such as coworking spaces, makerspaces, and tech and creative offices, reflect the strategies of both industrial entrepreneurs who control the tech labor force and place entrepreneurs who control land use, economic development policies, and municipal infrastructure. But they also respond to the needs and demands of workers, legacy industries, and marginalized constituencies.

Building a city's "innovation complex" requires material structures of buildings and land, social structures to train a workforce, and financial mechanisms to integrate public- and private-sector capital investment and direct it toward tech production (Zukin 2020). Moreover, as the word "complex" implies in a psychological sense, city leaders show a fear of losing ground economically if they cannot match the conditions for "innovation" set by other cities. As in other policy areas, competition is channeled by transnational organizations, consultants, and discussion forums that formulate and circulate a "global toolkit" of strategic solutions.

Local elites try to urbanize the "magic" of economic development in Silicon Valley by creating an unofficial governance system of entrepreneurial public-private-nonprofit partnerships among city governments, businesses, and nonprofit organizations. Looking at research centers like Silicon Valley in the 1990s, the sociologist Henry Etzkowitz (Etzkowitz and Leydesdorff 1995; Etzkowitz 2008) called this system of institutional alliances "the triple helix." But institutional networks are often also relational in a personal sense. In Silicon Valley, institutional relationships and personal ties were reinforced by social, racial, and gender exclusivity; the world of engineers, company founders, and venture capitalists was overwhelmingly white, male, and politically and culturally conservative, in contrast to the early influence of 1960 s counterculture on founders like Steve Jobs (O’Mara 2019). Most important to Silicon Valley, though, was generous funding from the federal government in the form of military contracts (Markusen et al. 1986; Mazzucato 2015; O’Mara 2019). These conditions were not available to cities in the 2010s. Despite the pro-technology, innovation policies of the Obama administration, after 2008, cities had to depend on other ways of raising public and private capital.

When Richard Florida and Martin Kenney (1988) looked at the tech industry in the 1980 s, they called attention to the concentration of innovation in a very small number of places - in fact, the same three superstar cities where the tech industry is concentrated now: San Francisco, Boston, and New York. Like Castells, they emphasized that venture capitalists tend to cluster in those places too. Florida and Kenney outline a social process - almost a social alchemy like the triple helix - that combines decisions made by individual tech workers and firms, networks of groups that control investment capital, and local culture in which tech knowledge is embedded. This alchemy of capital, culture, and tech talent brought cities back into the tech narrative in the 2010 s.

\section{Capital, culture, and tech talent}

The emergence and widespread use of the internet, and the continual development of more efficient tools to manipulate text and images online, increased demand for 
workers who could create web content. "New media producers" often did not have the same high level of tech skills as computer engineers. But during the 1980s, demand for their work grew along with demand for music content for the Sony Walkman (and later MP-3s) and video content for the VCR, very much like today's ravenous demand for video content for streaming platforms. Increased demand for creative content fueled dot-com jobs, investment, and business formation in New York and San Francisco. The geographer Allen Scott (2008) believed this "cognitive-cultural" turn in the economy enhanced the position of all big cities. Looking at Los Angeles and Paris during the 1990s, he (1997) found more production of goods and services with high levels of aesthetic or semiotic content than ever before. Innovations in digital technology would feed the growth of creative industries that are, for the most part, based in cities.

Richard Florida (2002) likewise saw a new "creative class" providing the base for urban economic growth. He was not thinking about painters and poets who lived in neo-bohemian, postindustrial lofts; he was thinking about new media producers and an even larger group of college-educated professionals who worked in knowledge and information industries - "the workforce devoted to technical creativity," he called them-as well as in the arts. Although he mistakenly included professionals like lawyers and accountants who do little creative work, his home in Pittsburgh and job at Carnegie Mellon University gave him a vantage point, outside of New York and San Francisco, to observe the effects a young population of college graduates could have on an old urban economy. Many Carnegie Mellon graduates got jobs in software and biotechnology; gradually, some began to stay in Pittsburgh instead of leaving to pursue careers in Silicon Valley. Florida believed that attracting the creative class - and convincing them to stay-would be crucial to Pittsburgh's survival.

Florida (2002) famously stated that all urban economies need to encourage "the three Ts": technology, talent, and tolerance. Of these, he believed, the driving force is talent. Places that are economically successful, Florida wrote, "are succeeding largely because creative people want to live there." Reversing the standard view that people migrate to follow jobs, he said, "Companies ... follow the people_ or, in many cases, are started by them." This inspired city governments that were searching for a growth engine to replace their old industrial base to build amenities that they could use to position themselves as "creative cities." They bet on the hypothesis that providing green space, bicycle paths, and cultural facilities, all much cheaper than affordable housing and more politically palatable than business subsidies, would help them to be winners in the global economy. Anxious to combat a deadly spiral of disinvestment and deindustrialization, elected officials did not consider it likely that these amenities would lead to gentrification and displacement of low-income residents. At any rate, politicians accepted these processes as the cost of attracting the "creative class" and establishing a "good business climate."

Both experientially and existentially, cities were different in the early 2000s. In the United States, the high crime rates of the 1980s and early 1990s were declining, although criminologists did not know why (Ford 2016). Gritty artists' districts like New York's SoHo were being replaced by even grittier hipster districts in Williamsburg and Bushwick. Cafés and restaurants sprouted in gentrifying neighborhoods, threatening longtime residents with both cultural and economic displacement - but this was accompanied by media buzz, image renewal, and real estate development that were important to city governments (Solnit and Schwartzenberg 2000; Lloyd 2006; Zukin 
2010). Forging a link between cultural capital and capital investment became significant on a global scale. While hipsters and "creative" tech firms inadvertently seeded the ground for real estate developers in Brooklyn and the Mission District, a "Cool Britannia" meme buoyed London's reputation, the Guggenheim Museum headlined postindustrial development in Bilbao, and Asian countries led by the Republic of Korea tried to overcome a regional economic crisis by developing the "soft power" of pop music and cuisine.

To urban elites, everything looked, well, cool until 2008. But the "creative city" model could not overcome the financial damage and cutbacks in jobs caused by the Great Recession. Amid efforts to devise a new strategic vision for economic growth, ideas began to circulate about building urban "innovation districts." These areas would take advantage of young people's attraction to city life, as Richard Florida described it, but instead of featuring artists, they would capitalize on the intellectual property of "downtown universities" that produced more inventions, deals, and startups per student than their counterparts in suburbs and college towns (Andes 2017). Urban innovation districts would follow the lead of "eds and meds" co-location, where life sciences labs at research universities partnered with pharmaceutical and biotechnology companies to create new, marketable products and, most important for city officials, jobs (Harkavy and Zuckerman 1999).

"Innovation district" was the chosen name for physically dense production districts comprised of research labs, business incubators for tech startups, coworking spaces, "creative" and corporate tech offices, and makerspaces for building and using computer hardware. Updating the assumptions of the regional industrial district model that had been discussed but rejected by neoliberal governments in the 1980s, researchers at the Brookings Institution (Muro and Katz 2010; Katz and Bradley 2013; Katz and Wagner 2014) proposed that the co-location of companies and researchers would generate informal social networks for the transfer of knowledge and the development of new ideas. Unlike regional industrial districts that emerged organically, new urban innovation districts would be planned and built by a city's business, government, and university leaders: the same "triple helix" that had built Silicon Valley. But the diversity of urban cultures would enable innovation districts to capture "talent" who wanted the social and cultural stimulation a city offered. "The trend," according to a 2009 article in Business Week (Engardio 2009), "is to nurture living, breathing communities rather than sterile, remote compounds of research silos." When economic development experts promoted the concept in reports and conferences around the world, it became clear that innovation districts promised to bring "Silicon Valley" to all cities, even New York (for a critical view of the limits of this model, see Kratke 2011).

I do not want to exaggerate a uniform movement toward an urban tech economy throughout the world. The geography of tech production varies according to the production strategies of major tech companies, their connections to research universities, and the competitive ability of politicians from different cities and regions to attract capital investment from their national government. Some regions, especially rural regions, may be less eager to get tech investment. Moreover, there has always been a multiplicity of tech centers in urban, suburban, and exurban settings. The coexistence of both "knowledge parks" and "science cities" in the United States, as the geographer Jennifer Clark (2014, p. 886) explains, reflects "the temporary, contingent, and competitive character of science and technology funding streams." The key factors, then, of 
an urban innovation complex are an activist city government, entrepreneurial universities, networks of institutional and private investors, and tech firms that are ready to move in (Ingallina 2012; Miao et al. 2015). These factors came together in New York after 2008 .

\section{From innovation districts to innovation complex}

New York was hit hard by the 2008 economic crisis. Yet, when the Wall Street investment bank Lehman Brothers failed and other major financial institutions teetered on the brink of collapse, the mayoral administration of Michael R. Bloomberg had no plan. The billionaire mayor, one of the richest people in the world, had made his fortune from an electronic device, the Bloomberg terminal, that brought financial data in real time to stock traders' desks. But, until the financial crisis, he had championed the big banks, advocating for less government regulation. The Bloomberg administration did support New York's media industry, especially TV and film production, but showed no special rapport with either the tech industry or its discourse of "Innovation and Entrepreneurship" until the Great Recession. The mayor then decided that the financial industry that had long dominated New York's economy had to step aside; new industries, from green manufacturing to software development, must rise (Zukin 2020; also see Indergaard 2019).

To confront the crisis, the New York City Economic Development Corporation (NYCEDC), the nonprofit public corporation that is, in effect, the city's economic development agency, created a Center for Economic Transformation and charged it with shaping the city's first-ever strategic plan. NYCEDC recruited a former management consultant who had worked at McKinsey and the World Economic Forum to run the center. He organized a months-long series of high-level discussions in industry sectors other than finance and hired outside consultants to analyze their needs. According to the emerging consensus, the city's "legacy" industries - chiefly media, fashion, and education — needed to develop their use of digital technology. New York should also expand its supply of computer engineers. The city's private and public universities must become more entrepreneurial in commercializing the ideas - the intellectual property - of their faculty and students; the startups that would emerge from their collaborations with corporations would create jobs. Although successful New Yorkbased startups in e-commerce (like Etsy), media (Buzzfeed, Vice), and social media (Foursquare) garnered attention, the city in fact offered multiple markets for potential B2B (business-to-business) tech firms.

The New York city government did not officially designate any innovation districts. Yet, by 2010, four types of innovation districts had emerged de facto if not de jure. The first type, that I like to call a naturally occurring innovation district, had been seeded during the dot-com boom of the 1990s; it included Silicon Alley, running down Broadway along Manhattan's commercial spine, and DUMBO, a dilapidated, partly abandoned industrial area on the north Brooklyn waterfront. Some Internet-based businesses in both areas managed to survive the one-two punch of the dot-com bust in 2000 and the economic recession that followed 9/11, the date when terrorists attacked the World Trade Center, in 2001. In the aftermath of these events, tech workers and founders in Silicon Alley generated a new "community," as they call it, 
from informal meetups and networks. At the same time, a small number of venture capitalists who had also lived through the dot-com bust gradually began to raise new funds to invest in a new generation of tech startups. New York still had massive wealth; $\mathrm{VCs}$ and the city government began to channel it, in different ways, into tech production.

Some of the capital investment funded new workspaces for tech startups, and some of those startups clustered in Silicon Alley and DUMBO. As both signs of life after 9/ 11 and rent-paying commercial tenants, they were welcomed by building owners, real estate developers, and the local public-private business associations called business improvement districts, in which real estate interests are well represented. The two tech clusters also benefited from their continued association with the "creative class," for their old brick and cast iron buildings embodied an industrial chic aesthetic, they had new green space in nearby public parks, and they offered relatively cheap commercial rents. It helped New York that Google opened a large office in West Chelsea, near the northern end of Silicon Alley, in 2006, and gradually expanded by buying five buildings there. As the New York Times (Bagli 2018) reports, "Google became a siren for other, smaller tech firms to move to the neighborhood, which was beginning to shrug off its industrial roots." At the same time, computer-savvy artists, writers, and app developers moved to Brooklyn and set up media offices, digital branding agencies, graphic design firms, and workshops near where they lived. This helped to grow the tech and media cluster that had first appeared in DUMBO in the 1990s. By 2015, this cluster extended for ten miles along the East River waterfront from Astoria, in Queens, to Brooklyn's Sunset Park.

The second type of de facto innovation district, a greenfield development, is represented by a single site: the newly built campus of Cornell Tech on Roosevelt Island, in the middle of the East River between Manhattan and Queens. When the post2008 crisis discussions among business elites pointed to a need for more computer engineers, the Bloomberg administration decided to establish a postgraduate engineering school that would produce them. Following Stanford's example, the school would both connect students and faculty to local companies and encourage them to set up their own startups. NYCEDC organized a worldwide competition for a university to develop and manage the engineering school; after a year of suspense, they awarded the contract to a partnership of Cornell University and the Israel Institute of Technology-Technion. Because Cornell's main campus was located upstate, the university already had New York State accreditation that would enable the new school to open quickly. Cornell also maintained a highly rated medical school and hospital on Manhattan's Upper East Side, suggesting that the university could quickly create synergy with startups in healthtech and biotech. For its part, Technion had an enviable track record for generating startups in its home city, Tel Aviv.

New York City promised to contribute $\$ 300$ million in city-owned land and infrastructure and give Cornell Tech $\$ 100$ million in cash. Through his private philanthropy, Mayor Bloomberg donated another \$100 million, enough to fund and name a building. Moreover, the school received a $\$ 350$ million donation from a Cornell graduate who had become wealthy from his ownership of duty-free shops. Within a year or two, Cornell Tech also received a $\$ 133$ million donation from the chairman of Qualcomm, a big semiconductor and wireless technology company based in San Diego, and his wife, both Cornell graduates. "We are delighted to partner with Cornell 
and the Technion on this unique educational initiative," the couple's announcement said, using the right buzzwords. "We believe strongly in the mission of this international collaboration to drive innovation and to foster economic development" (Kaminer 2013).

The third type of de facto innovation district prioritizes modern industrial development through computer-aided manufacturing, and is mainly based in three large, cityowned, industrial complexes on the East River in Brooklyn: the Brooklyn Navy Yard, Brooklyn Army Terminal, and Bush Terminal. This type of innovation district maintains the city government's social commitment to manufacturing by supporting relatively low rent for factory and workshop tenants, encouraging them to adopt computeraided production processes, and training manual workers to upgrade their skills. These workers are often first-generation immigrants, but they are voters, too; they represent a large and often vocal base for community organizations and progressive politicians. Candidates for public office ignore their demand to maintain manufacturing jobs at their peril. Municipal ownership gives these three industrial complexes financial leeway to sustain manufacturing tenants even though they pay a much lower rent than offices, hotels, or residential uses.

Within this small group of city-owned properties, the Brooklyn Navy Yard has been able to pursue a uniquely entrepreneurial path by building new facilities for both advanced and artisanal manufacturing, software production, and creative work. The Navy Yard's three hundred acres are managed by a nonprofit economic development corporation whose contract with the city specifies that the development corporation can use its rent revenues as it sees fit. This autonomy contrasts with other city-owned properties, whose rent revenues go directly into NYCEDC's coffers. Since the early 2000s, relative financial autonomy has allowed the Brooklyn Navy Yard Development Corporation to "leverage its rent rolls," in the words of a former CEO whom I interviewed in 2015, in order to raise private investment capital. BNYDC has aggressively pursued private capital, leasing land to real estate developers to build workspaces, including tech offices and coworking spaces, commercial kitchens, and workshops for computer hardware startups, and borrowing significant amounts of money from foreign investors in the form of EB-5 loans, which reward the lenders with visas and green cards for their families. In addition, the Navy Yard has received capital grants from NYCEDC in each of the last three mayoral administrations and smaller grants from New York State's economic development corporation, the Brooklyn borough president, and other local elected officials.

The Navy Yard has used these funding streams to renovate both infrastructure and buildings, some of which date back to the early 1900s. In partnership with private real estate developers, BNYDC has overseen the development of an extensive studio for film and TV production, the building of a well-equipped accelerator for both hardware and software startups, the transformation of a windowless, concrete warehouse into a glass-fronted building with food processing facilities and a ground-level food hall where the on-site food companies sell their products - for takeout only during the covid-19 pandemic. Partnering with several local universities and NYCEDC, the Brooklyn Navy Yard also hosts the first city-funded virtual reality and augmented reality lab in the United States. Moreover, BNYDC leased a narrow waterfront site to private real estate developers to erect a glamorous, new building where coworking spaces are managed by WeWork. As the website for this building, Dock 72, proclaims, 
"The Brooklyn Navy Yard has evolved from the old hub of New York's shipbuilding industry to the new epicenter of the city's creative class-A place where technology, design, food, film and modern manufacturing come together to collaborate and innovate."

Some of the financial arrangements that fund these facilities may well represent overly risky speculation. They take advantage of US tax laws - most recently, opportunity zones created by the Trump administration's tax law of 2017-as well as the EB5 visa program for foreign investors who create jobs. Yet, the Brooklyn Navy Yard Development Corporation is distinguished from most city government agencies around the world by their commitment to sustaining manufacturing and career paths to middleclass manufacturing jobs as a socially necessary part of urban innovation (interviews 2016, 2019).

Maintaining a social commitment to manufacturing in a city where real estate developers covet waterfront land for luxury condo construction requires the Navy Yard to use a range of programmatic innovations. First, the lower rents that manufacturing tenants pay are "cross-subsidized," in real estate lingo, by the higher rents paid by office tenants. Second, the Navy Yard runs an on-site job training program for lowincome, less educated neighborhood residents, many of whom live in public housing, veterans, and formerly incarcerated workers. After they complete their training, the development corporation tries to connect the workers to employers at the Navy Yard. They cannot create jobs for them, but they can set up pipelines to employers. With the same kind of pipelines in mind, the development corporation has established on-site apprenticeships for local high school students and a new STEAM (science, technology, engineering, arts, and math) high school for vocational training. Most important, BNYDC uses its partnerships with private-sector real estate developers to build modern factory, workshop, and studio space. By 2030, they plan to build new "vertical factories" with big, unobstructed floors. The vision is that manufacturing tenants will use digital technology designed and fabricated at the Navy Yard.

Although in many ways the Brooklyn Navy Yard constitutes an innovation district on its own, it is also one-third of the Brooklyn Tech Triangle, an imaginary construct that represents the fourth type of innovation district in New York. The "triangle" spans three distinct, adjacent spaces: the Brooklyn Navy Yard, its neighbor DUMBO to the south, and the borough's nearby historic downtown. It exists as a geographical space, to be sure, and includes 23 million square feet of office space, but the idea of a "tech triangle" was deliberately created as a branding device to direct attention and investment to this area (interviews 2015-2016).

The tech triangle was born in 2011 in the imagination of a former president of the Downtown [Brooklyn] Partnership, the borough's biggest business improvement district. Newly hired, he had been given a mandate to fill the vacant space in downtown's old office buildings. He looked out his office window one day, he told me, and thought about the booming demand for workspace both at the nearby Brooklyn Navy Yard and in DUMBO, just a few blocks away. He imagined a tech company that would design digital products at a studio in DUMBO, manufacture them at the Navy Yard, and conduct its corporate affairs from offices downtown. To make this fictional scenario real, he persuaded the president of DUMBO's business improvement district and the CEO of the Brooklyn Navy Yard Development Corporation to join him to commission a study of the three adjacent areas. 
The urban design studio that they hired discovered hundreds of tech companies, with owners and employees who were committed to this part of Brooklyn (WXY Architecture + Urban Design 2013). Many employees lived in Brooklyn and biked or walked to work. Presenting the three distinct areas as a coherent physical and social space, the architects felt, would highlight the area's strengths: thousands of workers at tech startups, almost 60,000 college students, and a creative vibe that was already Brooklyn's global brand.

The idea of a Brooklyn Tech Triangle got media buzz and politicians' support, and, during the next few years, without any official designation by the city or special authority, it assumed a material reality. New York University acquired both a historical engineering school in downtown Brooklyn, practically next door to the Downtown Partnership's office, and, a few blocks away, the big, empty, former headquarters of the Metropolitan Transportation Authority, which the university renovated into an "urban tech" research center. The Downtown Partnership set up recruiting events and internships to place local college students in tech firms. By 2016, vacant space in downtown Brooklyn's office buildings began to fill up, and new office construction was begun. In 2017, when NYCEDC submitted a bid to Amazon to build HQ2, the company's second headquarters, in New York, the Brooklyn Tech Triangle was among the four sites that they offered (NYCEDC 2017). By 2018, this area of Brooklyn had become the secondfastest-growing tech hub in the United States after San Francisco (Bowles et al. 2019).

Since 2010, the expanding geography of these four de facto innovation districts has anchored New York's tech ecosystem. The "innovation complex" includes flexible coworking spaces, many under the nearly ubiquitous WeWork sign until the company imploded in 2019 before the scrutiny of an impending IPO, as well as less visible but more important production spaces in independent tech and creative offices, tech incubators and accelerators, factories that use computer-aided manufacturing, and the offices of Big Tech companies like Google, Amazon, Facebook, and Apple. The ecosystem also depends on tech "community" organizations that promote startup culture, with its discourse of "Innovation and Entrepreneurship," and connect tech actors across organizations and fields. These actors are led by a soi-disant community of venture capitalists, successful startup founders, and representatives of Big Tech's New York offices. It includes entrepreneurial business and engineering students at local universities, including Cornell Tech, Columbia, and NYU, and software engineers, many from overseas. The whole assemblage of the innovation complex-discourses, organizations, and geographical spaces - has urbanized a version of Silicon Valley.

New York represents an early model. Since the late 1960s, its city government had adopted an entrepreneurial orientation in response to economic disinvestment, fiscal stress, and increasing protests and demands related to cutbacks in social welfare spending. Under extreme pressure from the federal government and the big banks, business and political leaders interpreted the situation partly as an image problem, partly as an urgent task of social control, and partly as a stimulus for a drastic change of governance from the Keynesian state to a market-oriented growth coalition exerting influence through a widening range of public-private-nonprofit partnerships (Harvey 1989; Greenberg 2008; Phillips-Fein 2017). This political reorientation reached national and eventually global scale when the policies of social control and fiscal austerity identified with Reaganism and Thatcherism in the 1980s starved cities' welfare and infrastructure budgets while giving free rein to private capital's expansion. By the 
2010s, the discourse of "Innovation and Entrepreneurship" those leaders had championed was fully identified with the tech industry, and the fictional scenario of fostering economic growth by encouraging tech startups swept through cities in every region of the world.

The innovation complex aims to recreate the city as modern, but it also reshapes it into a dystopian "social factory" (Tronti 1966; Negri 1989) where workspace and worktime spill over from the office and shop floor to hackathons, meetups, and cafés (Zukin and Papadantonakis 2018). Public parks are playgrounds and hangouts for tech "bros" (Adiv 2015; Stehlin 2016); universities teach "startup studios" to inculcate entrepreneurial zeal. The spatiality, then, of innovation districts, embeds these cultural effects in the urban landscape while camouflaging their institutional supports. They help cities to become, as the geographers Sami Moisio and Ugo Rossi (2020, p. 535) say, "state-orchestrated platforms for experimental governance and creative business activity." But they do this within a complicated urban matrix of political commitments to the city's social communities and power struggles to control land use.

\section{The urban matrix}

The layered discursive, geographical, and organizational interactions that have created New York's innovation complex indicate the complexity of developing a new economy in any big city. A city is an actor, an assemblage of markets and people, and both a spatial and an institutional framework for social action. It is an arena of contention with legal obligations, social communities, economic pressures, and political constituencies; it is caught in the middle, as liberal-democratic models of the state traditionally depict it, and also leans to the side of the most powerful interests, as described in neomarxist theories. Cities are shaped, moreover, by distinctly non-local forces: global flows of people and capital, to be sure, but also investments and policies made by other territorial levels of the state, manifesting what the sociologist Michael Indergaard (2019) calls "double embeddedness."

In the United States in recent years, the federal government has stepped back from investing in cities' economic base. But Moisio and Rossi (2020) argue that in Europe, at least, national states place cities at the forefront of "new economy" strategies. Looking at Italy and Finland, they see national governments focusing resources on urban champions-Milan and Helsinki-to recover from the 2008 financial crisis and combat the loss of domestic industries' competitive edge. The buildup of urban innovation centers is even more pronounced - and more widespread - in China. In all of these countries, the national government's policies work in tandem with the efforts of a city's place entrepreneurs and growth coalitions.

Urban business elites and their political allies have several goals. Using "the city as a growth machine," as Molotch's (1976) model suggests, they want to increase land values, make the city — or specific areas in it - attractive to other investors, and lay a foundation for future development. They need to burnish the city's image as a hotspot of innovation to draw tech companies and talent. They want to make the universities more entrepreneurial while limiting economic demands by other social groups. But they cannot do any of this without the support of elected officials who are politically 
committed to pursuing job creation for a much larger, more diverse, and economically poorer urban population.

The conflicts this implies do not always emerge into public view. With the growth of the urban tech economy, however, rising housing costs and social welfare cutbacks have made groups in the public more critical of city governments" "innovation" policies. On some proposed projects, like Amazon's plan to build its second national headquarters, HQ2, in New York (Goodman 2019) and Alphabet's plan to build a new, "smart" district on the waterfront in Toronto (DeVynck and Wong 2020), pushback against the project was fused with outrage at Big Tech. Mobilization against innovation policies and the powerful companies that benefit from them has been intense in the superstar cities where tech innovation is concentrated and housing costs are high, especially San Francisco, New York, and Seattle.

Innovation policies run the gamut from direct subsidies to individual tech businesses for promised job creation to indirect subsidies for workforce development through STEM (science, technology, engineering, and mathematics) curricula in public schools. Although research shows that paying companies to locate or maintain jobs in a specific place is not productive, elected officials nearly always feel vulnerable to firms' threats that they will move to where taxes are lower and other local governments are more generous (Schwartz 2018; Slattery and Zidar 2020). In San Francisco and Seattle, such threats, amplified by intense lobbying and public relations campaigns, have resulted in tax reductions for tech companies like Twitter and Amazon and even reversals of city council decisions. In New York, where a year-long process of bidding against more than two hundred other cities for Amazon's HQ2 was conducted in secret by the city and state, the mayor and governor orchestrated a $\$ 3$ billion subsidy package for the tech titan.

When the winning offer to Amazon was announced, to build on a waterfront site in Long Island City, in Queens, where the company would create more than 25,000 jobs, city council representatives and state legislators joined community groups in an uprising against it (Goodman 2019). Their vociferous opposition reflected anger that they had not been either consulted or informed about the deal and resentment that a trillion-dollar company led by the richest man in the world would get so much financial aid from the city and state government. They were also annoyed that Amazon would not commit to specific targets of job creation. But the bid to Amazon was ultimately undone by a wave of carefully mobilized public opinion against Big Tech in general and against specific Amazon policies as both a contractor to the US Immigration and Customs Enforcement agency (ICE) and an anti-union employer of warehouse workers. Faced with both scrutiny and opposition, Amazon withdrew. Yet the company proceeded to lease a large amount of office space in midtown Manhattan for a smaller number of employees.

It is important for tech companies to be present in big cities because cities are both platforms for developing new digital products and big markets for buying them (Clark 2020). The public sector alone is a significant customer: city governments buy digital equipment, from broadband to subway signals and traffic sensors, to modernize infrastructure and regulate "flows"; they pay tech companies to digitize public records and link citizens to public agencies through websites, email, and podcasts. City agencies buy or lease digital technology to count votes on election day, carry out the national census, and track public health crises. They issue contracts to tech companies 
to install public Wi-Fi links and hire cybersecurity firms to root out illegal hackers. The police, education, and transportation departments buy digital technology for surveillance and data analysis, including sensors that detect and count gunshot sounds. According to one report (Grandview Research 2020), the global market for smart city equipment is growing so fast that it will be worth $\$ 464$ billion in 2027 . Yet a city government's procurement contracts are not usually subject to broad public input or oversight.

Regulation is more open to public influence if public hearings are required, but more often it emerges into public view when proposed policies seek to curb specific products and platforms through legislation by the city council. Some platforms and the services they offer are so popular with users that public input supports the companies against government regulation, especially when the companies launch extensive public relations and lobbying campaigns to mobilize opposition. Airbnb, for example, is engaged in continual battles with city governments over occupancy taxes, zoning laws, and its control of a large share of the rental housing market; the company is one of the biggest lobbyists in New York City and State (Martineau 2017, 2019). Uber, likewise, is constantly pressuring city governments to allow them to put more cars on the streets and exercise less oversight of its treatment of drivers; in 2018, the company spent $\$ 6$ million on lobbying and advertising in New York City and State. But these companies' efforts spur energetic counter-lobbying by the embedded industries they "disrupt": the city's hotel industry and hotel workers' union and the medallion taxi industry and its drivers, all of which have often operated in collusion with city government agencies and elected officials, including the last two mayors (Marsh 2019; Rosenthal 2019).

Use of digital technology for surveillance generates continual protests despite general, though sometimes grudging, acknowledgment of risks from terrorism and violent crime. As in other cities, people are angry about the New York Police Department's use of facial recognition software, both because of its indiscriminate use in public spaces and the specific ways it enables racist discrimination. In the midst of Black Lives Matter demonstrations against police brutality, and after several years of discussion and litigation, the New York city council passed the Public Oversight of Surveillance Technology Act, which requires the police department to disclose to the public information about how they use surveillance technology (Brand 2020). Yet this law does not go as far as the city councils of other tech-forward cities - notably, San Francisco and Seattle-where elected officials have banned the use of facial recognition surveillance technology (Thadani 2019). Nevertheless, New Yorkers have even gone to the city's courts to regulate the Internet of Things, when tenants in privately owned apartment houses sued their landlord for replacing traditional metal keys with digital locks. The tenants argued that "smart" locks would enable the landlord to surveil their movements and keep a record of their guests ( $\mathrm{Ng} 2019)$.

Another contentious part of the urban matrix involves competition for land. After 2013, the development of "TAMI" (technology, advertising, media, and information) offices expanded dramatically in cities worldwide, and New York's real estate industry rushed to meet the growing demand. The market is not driven only by startups. The biggest tech companies, whose headquarters remain in the San Francisco Bay Area or Seattle, lease millions of square feet in new office towers in Manhattan. Before the covid-19 pandemic struck New York in 2020, Google, Facebook, and Amazon each planned to double their office space for an increased, combined workforce of 25,000. 
(Of course, this was the size of the projected workforce at Amazon's failed HQ2.) At the same time, however, not only startups and freelance tech and creative workers but also large corporations like IBM rented "flex space" by the month in a growing number of coworking spaces. By 2019, before the failure of their planned IPO, the coworking space management company WeWork had become the largest commercial tenant in New York City.

The crux of contention is that expansion of the TAMI office market puts pressure on space that can only be used legally for manufacturing. Venture capital, graphic design, and software firms have crept through Midtown South into Manhattan's historic Garment Center and filled old industrial complexes along the East River in Brooklyn, which are all still exclusively zoned for manufacturing use. In one contentious case, the owners of Industry City, a large, ironically renamed, old warehouse complex in Brooklyn's Sunset Park, proposed that the zoning be changed from heavy manufacturing to create a "special innovation district" that would allow them to lease space to TAMI offices, hotels, and bigger retail stores than are now permitted. This would potentially fill the space at higher rents than factory owners, metalworking shops, and woodworking shops can pay. Because zoning changes mandate public consultation, the developers pressed the local community board and the locally elected city council member to support their proposal. However, the mainly working-class community, made up of Chinese and Latino households, has kept up a strong opposition to the zoning change, and has pressed the city council member to join them. They fear that an innovation district will make it impossible to keep working-class jobs in the area; it will also encourage more residential gentrification by bringing more high-wage tech workers (Hum 2017, 2018). Community members have not been shy about expressing their opposition to a special innovation district, including raucous participation in meetings of the community board with the city council representative (Enman 2019a, b, 2020). Yet the proposal is making its way through a multi-year approval process with the support of the city planning department and the apparent support of the (progressive) mayor.

A similar proposal to carve an innovation district for TAMI offices out of an industrial zone in East Williamsburg, another part of north Brooklyn, is tracing a similar path through the approval process (New York City Department of City Planning 2019). Like residents of Sunset Park, the manufacturers, metal workers, craft brewers, and artisanal food makers in East Williamsburg are frustrated with the city government's disregard. They already find it hard to rent industrial space in an area that attracts illegal TAMI offices (interviews 2014, 2016).

As this array of policy issues shows, "emplacing" the tech economy in the urban matrix challenges the city government's ability to satisfy the demands of tech, financial, and real estate elites, embedded local industries, and marginalized social communities. Even when the common interest would seem to be served by job creation, government subsidies and land-use decisions, in the contentious climate of Big Tech's monopoly power and surveillance capabilities, spark resistance and outright revolt. Yet both support and opposition are more nuanced than might be supposed. In the case of Amazon's HQ2, construction workers' labor unions supported the big building project while the labor union representing Amazon warehouse workers, some community organizations, and most immigrants' rights organizations opposed it. Residents of the public housing project near the Amazon site, the largest public housing project in the 
United States, supported HQ2 despite meager prospects of jobs for them and widespread fears of gentrification. Citywide surveys showed most white New Yorkers opposed the bid for HQ2 while a majority of Black and Latino New Yorkers supported it (Vielkind 2019; "New York State Voters" 2019).

\section{On the brink}

Cities have become fault lines of digital technology, where the promise of economic growth to support the infrastructure of modern life confronts the power of tech companies to infiltrate the city's economy and reshape its physical form. Because cities have become major sites for developing, fabricating, and deploying new tech products, city governments are forced to regulate both platforms and markets despite their lack of expert knowledge and relatively few resources. Yet elected officials' enthusiastic support for "Innovation and Entrepreneurship" plunges them into an array of contentious issues, from old ones like capital-labor struggles and land-use conflicts to new, problematic uses of digital technology for surveillance and control. All these issues are complex, involve processes that unfold simultaneously on different territorial scales, and speak to different constituencies.

The high density and small size of cities, compared to national states, concentrates these conflicts of interest, brings opponents face to face in institutional arenas, and magnifies the stakes of hyperlocal conflicts. A zoning change in a Brooklyn waterfront district has consequences for which social classes can get jobs and afford homes in the city. A requirement that the New York Police Department at least disclose information about their use of surveillance technology offers an opportunity to protect privacy and save lives. The city council's decision to legalize electric bikes affects the fortunes of the platform companies that sell these vehicles and the futures of the mainly immigrant delivery workers who use them - and requires more regulation of city streets.

The covid-19 pandemic, by reorganizing production in terms of both working from home and expanding home deliveries of essential goods, strikes at both the high end and the low end of the urban tech economy. White collar and professional workers have the privilege of not going to the office, while health care and delivery workers must perform their jobs in dangerous conditions. Digital technology did not cause these changes. But social distancing and lockdown restrictions accelerated changes that were already underway in the tech "space": the geographical distribution of jobs not only in and around the city but around the world; the use of intelligent machines and other forms of automation to replace human labor; and the "virtualization" of meetings, health care, and education. No one knows how far these changes will go or how long they will last, but they have already reshaped traditional forms of communication and sociality. Working remotely, ordering online, and gathering in virtual events threaten the social, cultural, and economic materiality of urban life even as they enable the basic functions of human life to go on.

The spatiality of digital production is important for the future of any economy. If the conception, design, and prototyping of new digital products and platforms continue to cluster together with Big Tech and big capital, the future seems better for the small number of superstar cities that already have the most tech jobs. But looking at the behavior of the tech industry in the prism of a city strongly suggests that it acts no 
differently from any other industry. Tech companies seek government subsidies and release from taxes and regulation; they lobby and sometimes even threaten local governments to obtain favorable treatment. They also try to influence policy by contributing to city council campaigns and pro-business PACs (political action committees). Yet the tech industry has unique capabilities - not only to create jobs, especially highly paid jobs that mayors desire, but to remake the city for a new modernity. This is both a thrilling and an intimidating prospect.

New York's experience suggests that the presence of institutional investors and venture capital is the most important factor in creating an ecosystem to produce new digital technology. But New York is also a media center and a university hub, a collection of cultural hotspots for generating new fashions, and, for the time being, a popular place for young people to live. This would seem to bode well for a relatively small number of similar metropolitan cities. Yet despite the wealth of big tech corporations, the building of an innovation complex requires government investment. This poses significant questions about who controls the investment as well as who benefits from its rewards. In New York, despite a progressive mayor's commitment to job creation for "all New Yorkers," the city government remains dependent on Big Tech to create jobs and train "native" New Yorkers for them. Moreover, despite continued commitment to startup culture in both government and the tech community, Big Tech continues to buy successful startups and incorporate their "innovation" into their own business growth.

What would it take for a city government to resist the lure of a new modernity? To draft a different program of economic revival from that preferred by venture capitalists, big banks, and private equity investors? The first step is to recognize that "innovation" is an ideological discourse that brings different benefits to different social groups, maintains a highly skewed distribution of economic rewards, and aims to restore capitalism's charisma. Although cities make it easy to see these processes, it is not easy for cities to reverse their effects. The urbanization of the cultural forms identified with Silicon Valley has made cities dependent on both digital technology and the tech industry. Until a regulation regime is developed on a global scale, cities must be avatars of resistance.

\section{Compliance with ethical standards}

Conflict of interest Not applicable.

\section{References}

Adiv, N. (2015). Paying to play in the Mission District. https://www.metropolitiques.eu/Paying-to-Play-in-theMission.html, February 16. Accessed 10 Jan 2020.

Andes, S. (2017). Hidden in plain sight: The oversized impact of downtown universities. Washington DC: The Anne T. and Robert M. Bass Initiative on Innovation and Placemaking, Brookings Institution. https://www.brookings.edu/wp-content/uploads/2017/10/2017-10-10_ocs_bass_downtown_universities_ scott_andes_full.pdf. Accessed 5 July 2020.

Bagli, C. V. (2018). \$2.4 billion deal for Chelsea Market enlarges Google's New York footprint. https://www. nytimes.com/2018/02/07/nyregion/google-chelsea-market-new-york.html, 7 February. Accessed 19 Sept 2019.

Beckert, J. (2016). Imagined futures: Fictional expectations and capitalist dynamics. Cambridge: Harvard University Press. 
Belussi, F., \& Caldari, K. (2009). At the origin of the industrial district: Alfred Marshall and the Cambridge school. Cambridge Journal of Economics, 33(2), 335-355.

Boltanski, L., \& Chiapello, E. (2005). The new spirit of capitalism, trans. G. Elliott. London: Verso.

Bowles, J., Dvorkin, E., Sharp, N., \& Shaviro, C. (2019). Brooklyn's growing innovation economy. New York: Center for an Urban Future. https://nycfuture.org/pdf/Brooklyns_Growing_Innovation_ Economy_6-12.pdf. Accessed 5 July 2020.

Boy, J. D., \& Uitermark, J. (2017). Reassembling the city through Instagram. Transactions of the Institute of British Geographers, 42(4), 612-624.

Brand, D. (2020). Council passes bill compelling NYPD to share surveillance strategies. https:/queenseagle. com/all/council-passes-bill-compelling-nypd-to-share-surveillance-strategies, 18 June. Accessed 6 July 2020.

Brooker, K. (2015). Goldman in ventureland. https://www.bloomberg.com/news/features/2015-07-28/howgoldman-sachs-became-a-tech-investing-powerhouse, 28 July. Accessed 13 January 2020.

Castells, M. (1989). The informational city: Information technology, economic restructuring, and the urbanregional process. Oxford: Basil Blackwell.

Castells, M., \& Hall, P. (1994). Technopoles of the world: The making of twenty-first-century industrial complexes. London: Routledge.

Clark, J. (2014). Siting "scientific spaces" in the US: The push and pull of regional development strategies and national innovation policies. Environment and Planning C: Government and Policy, 32(5), 880-895.

Clark, J. (2020). Uneven innovation: The work of smart cities. New York: Columbia University Press.

Compass. (2015). The global startup ecosystem ranking 2015. https://startupgenome.com/blog/the-2015global-startup-ecosystem-ranking, 27 July. Accessed July 52020.

DeVynck, G., \& Wong, N. (2020). Alphabet's dream of a smart city in Toronto is over. https://www. bloomberg.com/news/articles/2020-05-07/alphabet-s-dream-of-a-smart-city-in-toronto-is-over, 7 May. Accessed 5 July 2020.

DiMaggio, P., \& Garip, F. (2012). Network effects and social inequality. Annual Review of Sociology, 38, 93118.

Engardio, P. (2009). Research parks for the knowledge economy. https://www.bloomberg. com/news/articles/2009-06-01/research-parks-for-the-knowledge-economy, 1 June. Accessed 5 July 2020.

Enman, S. (2019a). Industry City expansion will not happen without broader Sunset Park investment, pol pledges. https://brooklyneagle.com/articles/2019/09/17/industry-city-expansion-will-not-happen-withoutbroader-sunset-park-investment-pol-pledges/, 17 September. Accessed 15 Jan 2020.

Enman, S. (2019b). Industry City moves forward with expansion, shocking local leaders. https://brooklyneagle.com/articles/2019/10/28/industry-city-moves-forward-with-expansion-shockinglocal-leaders/, 28 October. Accessed 15 Jan 2020.

Enman, S. (2020). Hearing on Industry City expansion ends early due to interruptions-again. https://brooklyneagle.com/articles/2020/01/15/hearing-on-industry-city-expansion-ends-early-due-tointerruptions-again/, 15 January. Accessed 15 Jan 2020.

Etzkowitz, H. (2008). The triple helix: University-industry-government innovation in action. New York: Routledge.

Etzkowitz, H., \& Leydesdorff, L. (1995). The triple helix: University-industry-government relations: A laboratory for knowledge-based economic development. EASST Review, 14, 14-19.

Florida, R. (2002). The rise of the creative class. New York: Basic Books.

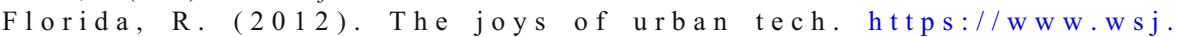
com/articles/SB10000872396390444914904577619441778073340, 31 August. Accessed 13 Jan 2020.

Florida, R., \& Kenney, M. (1988). Venture capital, high technology and regional development. Regional Studies, 22(1), 33-48.

Ford, M. (2016). What caused the great crime decline in the U.S.? www.theatlantic.com/politics/archive/2016 /04/what-caused-the-crime-decline/477408/, 15 April. Accessed 17 Sept 2019.

Gertner, J. (2012). The idea factory: Bell Labs and the great age of American innovation. New York: Penguin.

Goodman, J. D. (2019). Amazon pulls out of planned New York City headquarters. https://www.nytimes. com/2019/02/14/nyregion/amazon-hq2-queens.html, 14 February. Accessed 3 July 2020.

Grandview Research. (2020). Smart cities market size worth $\$ 463.9$ billion by 2027. https://www. grandviewresearch.com/press-release/global-smart-cities-market, February. Accessed 1 July 2020.

Greenberg, M. (2008). Branding New York: How a city in crisis was sold to the world. New York: Routledge. Gyourko, J., Mayer, C., \& Sinai, T. (2006). Superstar cities. National Bureau of Economic Research working paper 12355. Cambridge: National Bureau of Economic Research, July. https://www.nber. org/papers/w12355.pdf. Accessed 14 Jan 2020. 
Harkavy, I., \& Zuckerman, H. (1999). Eds and meds: Cities' hidden assets. Washington DC: Center on Urban \& Metropolitan Policy, Brookings Institution, August. https://www.brookings.edu/wpcontent/uploads/2016/06/09_community_development_report.pdf. Accessed 5 July 2020.

Harvey, D. (1989). From managerialism to entrepreneurialism: The transformation in urban governance in late capitalism. Geografiska Annaler, Series B, 71(1), 3-17.

Hum, T. (2017). "Get ready Sunset Park, Brooklyn is coming": The real estate imperatives of an innovation ecosystem. https://www.progressivecity.net/single-post/2017/07/11/\%E2\%80\%9CGET-READYSUNSET-PARK-\%E2\%80\%98BROOKLYN\%E2\%80\%99-IS-COMING\%E2\%80\%9D-THE-REALESTATE-IMPERATIVES-OF-AN-INNOVATION-ECOSYSTEM, 11 July. Accessed 13 Jan 2020.

Hum, T. (2018). Opinion: Supercharging the gentrification of Sunset Park. https://www.gothamgazette. com/opinion/8043-supercharging-the-gentrification-of-sunset-park, 3 November. Accessed 13 Jan 2020.

Indergaard, M. (2004). Silicon alley: The rise and fall of a new media district. New York: Routledge.

Indergaard, M. (2019). A developmental network city? Double embeddedness in New York. Cambridge Journal of Regions, Economy and Society, 12(3), 385-399.

Ingallina, P., ed. (2012). Universités et enjeux territoriaux: Une comparaison internationale de l'économie de la connaissance. Villeneuve d'Ascq: Presses universitaires du Septentrion.

Kaminer, A. (2013). Gift to help Cornell Tech school offer an innovative program. www.nytimes.com/2013 /04/23/nyregion/planned-cornell-tech-school-gets-133-million-gift.html, 22 April. Accessed 17 Sept 2019.

Katz, B., \& Bradley, J. (2013). The metropolitan revolution: How cities and metros are fixing our broken politics and fragile economy. Washington DC: Brookings Institution.

Katz, B., \& Wagner, J. (2014). The rise of innovation districts: A new geography of innovation in America. Washington DC: Metropolitan Policy Program, Brookings Institution, May. https://c24215cec6c97b637 db6-9c0895f07c3474f6636f95b6bf3db172.ssl.cf1.rackcdn.com/content/metro-innovationdistricts/ /media/programs/metro/images/innovation/innovationdistricts1.pdf. Accessed 5 July 2020.

Kelso, A. (2018). How becoming 'a tech company that sells pizza' delivered huge for Domino's. https://www. forbes.com/sites/aliciakelso/2018/04/30/delivery-digital-provide-dominos-with-game-changingadvantages/\#67438c597771, 30 April. Accessed 13 Jan 2020.

Kratke, S. (2011). The creative capital of cities: Interactive knowledge creation and the urbanization economies of innovation. Malden: Wiley-Blackwell.

Levin, M.R., Forgan, S., Hessler, M., Kargon, R.H., \& Low, M. (2010) Urban modernity: Cultural innovation in the second industrial revolution. Cambridge MA: MIT Press.

Lloyd, R. (2006). Neo-bohemia: Art and culture in the postindustrial city. New York: Routledge.

Logan, J. R., \& Molotch, H. L. (1986). Urban fortunes: The political economy of place. Berkeley: University of California Press.

Markusen, A. R., Hall, P., \& Glasmeier, A. K. (1986). High-tech America: The when, how, where, and why of the sunrise industries. Boston: Allen and Unwin.

Martineau, P. (2017). Here's how much Airbnb spent on lobbying in the first half of 2017. https://therealdeal. com/2017/08/07/heres-how-much-airbnb-spent-on-lobbying-in-the-first-half-of-2017/, 8 August. Accessed 14 Jan 2020.

Martineau, P. (2019). Inside Airbnb's “guerrilla war" against local governments. https:/www.wired. com/story/inside-airbnbs-guerrilla-war-against-local-governments/<, 20 March. Accessed 14 Jan 2020.

Marsh, J. (2019). Nearly 30\% of de Blasio's campaign funds came from New York hotel industry. https://nypost.com/2019/09/02/nearly-30-percent-of-de-blasios-campaign-funds-came-from-new-yorkhotel-industry/, 2 September. Accessed 12 Aug 2020.

Mazzucato, M. (2015). The entrepreneurial state: Debunking public vs. private sector myths. New York: Public Affairs.

Miao, J. T., Benneworth, P., \& Phelps, N. A. (Eds.). (2015). Making $21^{\text {st }}$ century knowledge complexes: Technopoles of the world revisited. Abingdon: Routledge.

Moisio, S., \& Rossi, U. (2020). The start-up state: Governing urbanised capitalism. Environment and Planning A: Economy and Space, 52(3), 532-552.

Molotch, H. (1976). The city as a growth machine: Toward a political economy of place. American Journal of Sociology, 82(2), 309-332.

Moretti, E. (2012). The new geography of jobs. New York: Houghton Mifflin Harcourt.

Mozingo, L. A. (2011). Pastoral capitalism: A history of suburban corporate landscapes. Cambridge: MIT Press.

Muro, M., \& Katz, B. (2010). The new "cluster moment": How innovation clusters can foster the next economy. Washington DC: Metropolitan Policy Program, The Brookings Institution, September. 
https:/www.brookings.edu/wp-content/uploads/2016/06/0921_clusters_muro_katz.pdf. Accessed 5 July 2020.

Negri, A. (1989). The politics of subversion: A manifesto for the twenty-first century. Cambridge: Polity.

New York City Department of City Planning. (2019). North Brooklyn industry and innovation plan, April. https:/www1.nyc.gov/site/planning/plans/north-brooklyn-vision-plan/north-brooklyn-vision-planupdates.page. Accessed 16 Jan 2020.

New York City Economic Development Corporation. (2017). New York City submits proposal for Amazon's second headquarters. www.nycedc.com/press-release/new-york-city-submits-proposal-amazon-s-secondheadquarters, 18 October. Accessed 20 Sept 2019.

New York State voters support Amazon-type deals 2-1, Quinnipiac University poll finds. (2019). https://poll. qu.edu/images/polling/ny/ny03202019 noze22.pdf/, 20 March. Accessed 24 Mar 2019.

$\mathrm{Ng}$, A. (2019). Tenants win as settlement orders landlords give physical keys over smart locks. https://www. cnet.com/news/tenants-win-rights-to-physical-keys-over-smart-locks-from-landlords/, 7 May. Accessed 15 Jan 2020.

O'Mara, M. P. (2005). Cities of knowledge: Cold war science and the search for the next Silicon Valley. Princeton: Princeton University Press.

O'Mara, M. P. (2019). The code: Silicon Valley and the remaking of America. New York: Penguin.

Phillips-Fein, K. (2017). Fear city: New York's fiscal crisis and the rise of austerity politics. New York: Metropolitan Books.

Ravenelle, A.J. (2019). Hustle and gig: Struggling and surviving in the sharing economy. Oakland CA: University of California Press.

Rosenthal, B.M. (2019). 'They were conned': How reckless loans devastated a generation of taxi drivers. https://www.nytimes.com/2019/05/19/nyregion/nyc-taxis-medallions-suicides.html, 19 May. Accessed 12 Aug 2020.

Saxenian, A.-L. (1994). Regional advantage: Culture and competition in Silicon Valley and Route 128. Cambridge: Harvard University Press.

Schwartz, A. (2018). The realities of economic development subsidies. https://www.americanprogress. org/issues/economy/reports/2018/11/01/457771/realities-economic-development-subsidies/, 1 November. Accessed 14 Jan 2020.

Scott, A.J. (1997) The cultural economy of cities. International Journal of Urban and Regional Research, 21(2), 323-339.

Scott, A.J. (2008) Social economy of the metropolis: Cognitive-cultural capitalism and the global resurgence of cities. Oxford: Oxford University Press.

Semi, G., \& Tonetta, M. (2020). Marginal hosts: Short-term rental suppliers in Turin, Italy. Environment and Planning A: Economy and Space. https://doi.org/10.1177/0308518X20912435, 13 March. Accessed 1 Apr 2020.

Slattery, C., \& Zidar, O. (2020). Evaluating state and local business tax incentives. Journal of Economic Perspectives, 34(2), 90-118.

Solnit, R., \& Schwartzenberg, S. (2000). Hollow city: The siege of San Francisco and the crisis of American urbanism. London: Verso.

Stehlin, J. (2016). The post-industrial "shop floor": Emerging forms of gentrification in San Francisco's innovation economy. Antipode, 48(2), $474-493$.

Storper, M. (1995). The resurgence of regional economies, ten years later: The region as a nexus of untraded interdependencies. European Urban and Regional Studies, 2(3), 191-221.

Storper, M., Kemeny, T., Makarem, N., \& Osman, T. (2015). The rise and fall of urban economies: Lessons from San Francisco and Los Angeles. Palo Alto: Stanford Business Books.

Terranova, T. (2000) Free labor: Producing for the digital economy. Social Text, 18(2), 33-58.

Thadani, T. (2019). San Francisco bans city use of facial recognition surveillance technology. https://www. sfchronicle.com/politics/article/San-Francisco-bans-city-use-of-facial-recognition-13845370.php?psid=4 m7j0, 14 May. Accessed 6 July 2020.

Thrift, N. (2001). "It's the romance, not the finance, that makes the business worth pursuing": Disclosing a new market culture. Economy and Society, 30(4), 412-432.

Trigilia, C. (2007). Unbalanced growth: Why is economic sociology stronger in theory than in policies? Current Sociology, 55(1), 59-74.

Tronti, M. (1966). Operai e capitale. Turin: Einaudi.

Vielkind, J. (2019). Majority of New Yorkers support Amazon project in Queens, poll shows. https://www. wsj.com/articles/majority-of-new-yorkers-support-amazon-project-in-queens-new-poll-shows11549967400?mc_cid=28df8d0231\&mc_eid=de226b4f79, 12 February. Accessed 13 Feb 2019. 
Vitale, P. (2017). Making science suburban: the suburbanization of industrial research and the invention of "research man". Environment and Planning A: Economy and Space, 49(12), 2813-2834.

Walker, R. A. (2018). Pictures of a gone city: Tech and the dark side of prosperity in the San Francisco Bay Area. Oakland: PM Press.

Wolfe, M.R. (1999). The wired loft: Lifestyle innovation diffusion and industrial networking in the rise of San Francisco's Multimedia Gulch. Urban Affairs Review, 34(5), 707-728.

WXY Architecture + Urban Design. (2013). Brooklyn tech triangle strategic plan. Brooklyn: Brooklyn Navy Yard Development Corporation, Downtown Brooklyn Partnership, and DUMBO Business Improvement District.

Zukin, S. (2010). Naked City: The death and life of authentic urban places. New York: Oxford University Press.

Zukin, S. (2020). The innovation complex: Cities, tech, and the new economy. New York: Oxford University Press.

Zukin, S., \& Papadantonakis, M. (2018). Hackathons as co-optation ritual: Socializing workers and institutionalizing innovation in the "new" economy. Research in the Sociology of Work, 31, 157-181.

Publisher's note Springer Nature remains neutral with regard to jurisdictional claims in published maps and institutional affiliations.

Sharon Zukin is professor emerita of sociology at Brooklyn College and the Graduate Center of the City University of New York. She recently published The Innovation Complex: Cities, Tech, and the New Economy (Oxford University Press 2020) and made a short video about New York's tech economy with the documentary filmmaker Alice Arnold, https://www.youtube.com/watch?v=gI8rA3QGWhk. Zukin writes about urban cultures and economies around the world. 